\title{
Tectonic tremor and deep slow slip on the Alpine Fault
}

\author{
A. G. Wech, ${ }^{1}$ C. M. Boese, ${ }^{1}$ T. A. Stern, ${ }^{1}$ and J. Townend ${ }^{1}$ \\ Received 21 March 2012; revised 13 April 2012; accepted 16 April 2012; published 19 May 2012.
}

[1] Tectonic tremor is characterized by persistent, lowfrequency seismic energy seen at major plate boundaries. Although predominantly associated with subduction zones, tremor also occurs along the deep extension of the strike-slip San Andreas Fault. Here we present the first observations of tectonic tremor along New Zealand's Alpine Fault, a major transform boundary that is late in its earthquake cycle. We report tectonic tremor that occurred on the central section of the Alpine Fault on 12 days between March 2009 and October 2011. Tremor hypocenters concentrate in the lower crust at the downdip projection of the Alpine Fault; coincide with a zone of high $\mathrm{P}$-wave attenuation (low $\mathrm{Q}_{\mathrm{p}}$ ) and bright seismic reflections; occur in the $25-45 \mathrm{~km}$ depth range, below the seismogenic zone; and may define the deep plate boundary structure extending through the lower crust and into the upper mantle. We infer this tremor to represent slow slip on the deep extent of the Alpine Fault in a fluid-rich region marked by high attenuation and reflectivity. These observations provide the first indication of present-day displacement on the lower crustal portion of the AustraliaPacific transform plate boundary. Citation: Wech, A. G., C. M. Boese, T. A. Stern, and J. Townend (2012), Tectonic tremor and deep slow slip on the Alpine Fault, Geophys. Res. Lett., 39, L10303, doi:10.1029/2012GL051751.

\section{Introduction}

[2] New Zealand straddles the boundary between the Australian and Pacific plates, whose collision has formed three distinct tectonic regimes spanning the country's two main islands. Beneath the North Island, this boundary is manifest as westward subduction of the Pacific plate at the Hikurangi Trough. At the southern end of the South Island, the subduction polarity is reversed, with the Australian plate subducting eastward. In between, collision creates the Alpine Fault, a $650 \mathrm{~km}$-long transform fault. This transpressional structure, which runs the length of the South Island, accommodates most of the relative motion between the two plates: approximately $21-27 \mathrm{~mm} / \mathrm{yr}$ of the $37 \pm 2 \mathrm{~mm} / \mathrm{yr}$ relative plate motion occurs as dextral slip on the Alpine Fault, with the remaining plate motion accommodated through uplift and auxiliary faulting [Norris and Cooper, 2001; Sutherland et al., 2006].

[3] This study focuses on the central portion of the Alpine Fault, whose role in relieving strain accumulation remains

\footnotetext{
${ }^{1}$ School of Geography, Environment and Earth Sciences, Victoria University of Wellington, Wellington, New Zealand.

Corresponding author: A. G. Wech, School of Geography, Environment and Earth Sciences, Victoria University of Wellington, Cotton Building, Wellington 6012, New Zealand. (aaron.wech@vuw.ac.nz)

Published in 2012 by the American Geophysical Union.
}

poorly understood [Sutherland et al., 2007; Walcott, 1978]. Paleoseismic evidence suggests that the central Alpine Fault ruptures in $\mathrm{M}_{\mathrm{w}} \sim 7.9$ earthquakes every 200-400 years and that it last ruptured in 1717 [Sutherland et al., 2007]. Seismicity larger than $\mathrm{M}_{\mathrm{L}} \sim 2$ is particularly sparse in the region [Boese et al., 2012; Evison, 1971; Leitner et al., 2001], the Alpine Fault exhibits no evidence for present-day creep at the surface (based on repeated geodetic observations and the lack of distorted cultural structures) [Beavan et al., 1999; Sutherland et al., 2007], and interpreted GPS measurements indicate that the fault is locked to a depth of 13-18 km [Wallace et al., 2007]. These observations and the time elapsed since the last major earthquake suggest that the Alpine Fault is late in its earthquake cycle, making any observations of seismic or aseismic deformation critical in refining current hazard estimates.

[4] Tectonic tremor is an emergent, low-amplitude signal, that has durations of minutes to days and lacks the higherfrequency energy radiated by normal earthquakes [Obara, 2002]. First observed in subduction zones, tremor is often spatially and temporally correlated with geodetically observed slow slip [Bartlow et al., 2011; Obara et al., 2004]; however, this correlation can be complex [Kim et al., 2011; Peterson et al., 2011], and low-level tremor can occur without detectable slow slip [Wech et al., 2009]. A growing body of evidence suggests that tectonic tremor is the seismic signature of slow slip [Shelly et al., 2007, 2006; Wech and Creager, 2007], making tremor a useful tool in identifying slip below geodetic resolution [Shelly and Johnson, 2011; Wech and Creager, 2011]. On the San Andreas Fault-the only transform boundary where tremor has been observeddeep (20-40 km), low-level tremor occurs below a locked section of the fault [Nadeau and Dolenc, 2005]. This seismic signal occurs without any associated geodetic signal [Johnston et al., 2006] and is inferred to reflect deep, slow shear in the brittle-ductile transition zone [Nadeau and Dolenc, 2005].

[5] Here, we report on tectonic tremor occurring along the deeper extension of the central portion of the Alpine Fault. Our observations suggest that slow slip occurs within the mid- to lower-crust or upper mantle, relieving stress in the transition zone from brittle to ductile behavior along the transform boundary between the Pacific and Australian plates. As our only present-day indicator of active deformation on the Alpine Fault, tremor provides a unique means of documenting and elucidating ambient coupling and stress conditions along this portion the plate boundary.

\section{Data and Observations}

[6] We overcome some of the inherent obstacles associated with identifying tremor using a combination of seismic data from New Zealand's permanent broadband GeoNet network [Petersen et al., 2011] and the Southern Alps Microearthquake Borehole Array (SAMBA), a network of 11 short-period 


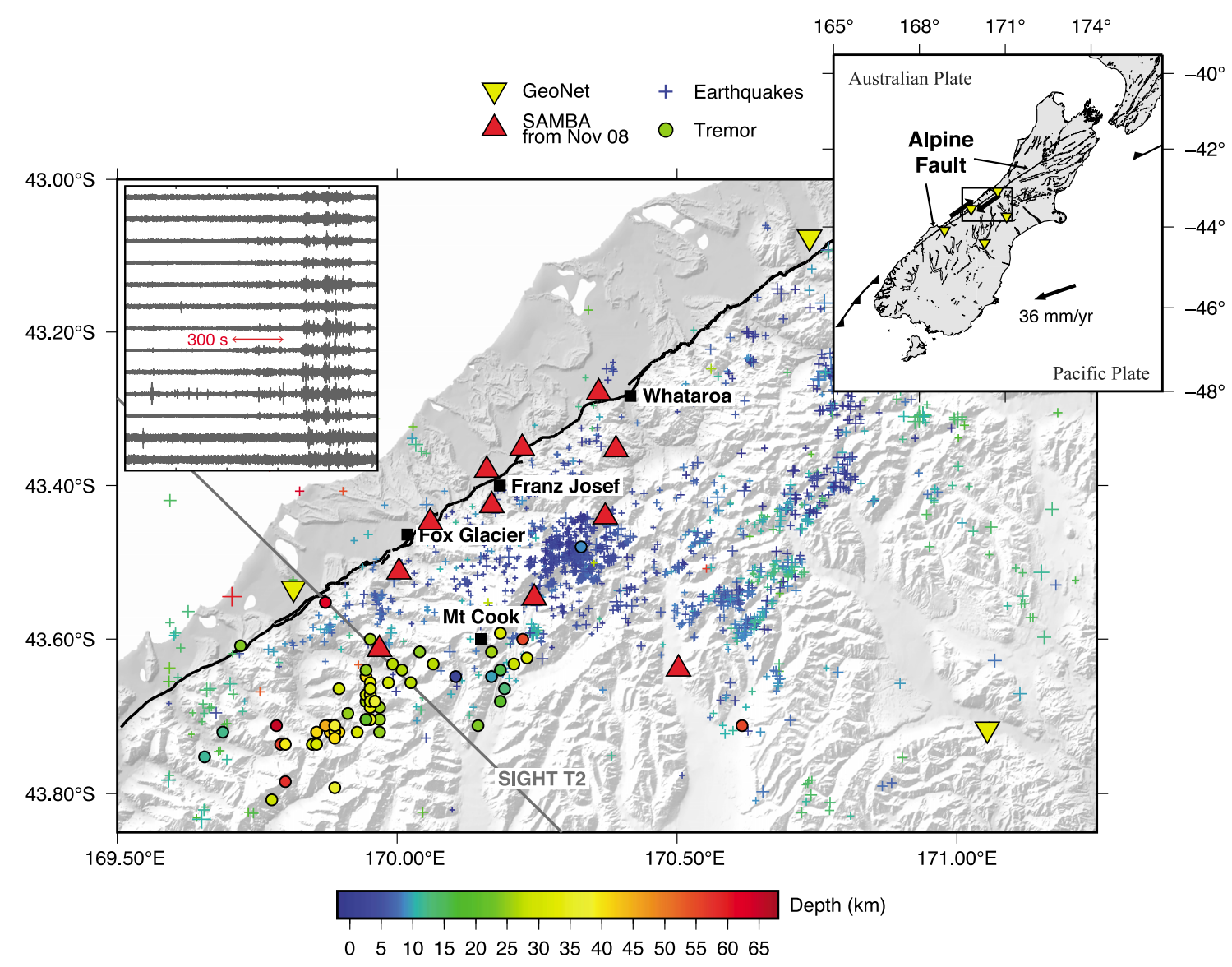

Figure 1. Earthquakes (crosses) and tremor locations (dots), color-coded with depth. Red and yellow triangles denote SAMBA and GeoNet seismic stations used in this study, respectively. The Alpine Fault trace is shown in black. Upper left inset shows 25 minutes of filtered horizontal-component seismograms (starting at 16:40 on 14 July 2010) containing tremor, recorded at 13 stations (10 SAMBA and the three western-most GeoNet stations) ordered by latitude. The SIGHT T2 (gray line) transect is shown through the tremor region.

seismometers installed in 2-100 m-deep boreholes, that spans the central Alpine Fault (Figure 1) [Boese et al., 2012]. As tremor lacks impulsive arrivals, it is usually identified by searching for persistent, coherent energy recorded at several sites [Kao and Shan, 2004]. However, detecting such coherence is difficult at large distances because of the signals' low amplitudes. SAMBA's $\sim 60 \mathrm{~km}$ aperture and dense station spacing (with average inter-station distances of 8 and $16 \mathrm{~km}$ parallel and perpendicular to the strike of the Alpine Fault, respectively) make it easier to identify and locate the source of low-amplitude, emergent signals than using GeoNet alone (80-100 km station spacing).

[7] We have performed a systematic search for tremor using continuous seismic data spanning the interval from March 2009 to October 2011. High noise levels produced by local seismicity or local geomorphic processes (e.g., rockfalls, glacier movement, icefalls etc.) precluded the use of an automated detection method, and we therefore undertook a manual search for tremor activity. The east components of data from all stations are band-pass filtered from $1-6 \mathrm{~Hz}$, rectified into envelopes, smoothed using a $20 \mathrm{~s}$ low-pass filter, and decimated to $1 \mathrm{~Hz}$. The resulting envelope functions are inspected visually to identify persistent, coherent signals.

[8] The identified tremor windows are then reprocessed to determine hypocenters. All available data are filtered from $2-$
$10 \mathrm{~Hz}$ (to take advantage of the observed tremor bandwidth), rectified into envelopes, low-pass filtered at $0.2 \mathrm{~Hz}$, and decimated at $5 \mathrm{~Hz}$. We separate each visually identified tremor window into individual bursts that are located systematically with a waveform envelope cross-correlation technique [Wech and Creager, 2008] using those channels with normalized cross-correlation values of $>0.7$. This method introduces epicentral uncertainties of approximately $8 \mathrm{~km}$, but the alternative approach of cross-correlating smoothed envelopes provides poor depth constraints, which are exacerbated here by the tremor's occurrence outside the SAMBA network. Magnitudes have been calculated by calibrating the maximum amplitude of the signal at each station with those determined for earthquakes, which have in turn been calibrated to the GeoNet catalog [Boese et al., 2012].

[9] During the 2.5 years examined, we find 12 days on which tremor activity occurred and locate 65 individual bursts (Figure $\mathrm{S} 1$ in the auxiliary material). ${ }^{1}$ Most of the tremor occurs beneath the Copland Valley on the southern edge of the SAMBA station network and extends $\sim 30 \mathrm{~km}$ further to the southwest (Figure 1). The 25-45 km-deep tremors (Figure 3) form a near-vertical band that is subparallel to but offset southeastward from the trace of the Alpine Fault

${ }^{1}$ Auxiliary materials are available in the HTML. doi:10.1029/ 2012GL051751. 


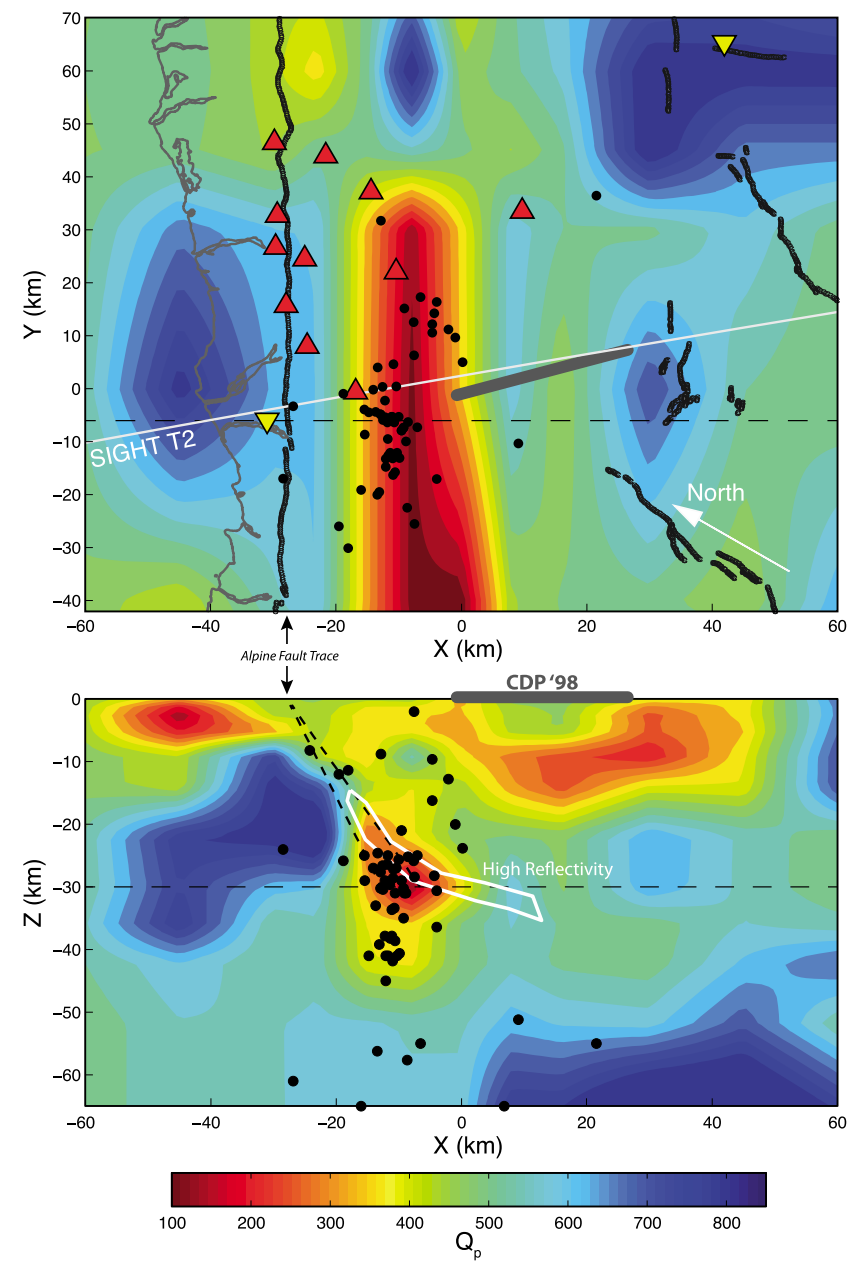

Figure 2. Tremor (black dots) and $\mathrm{Q}_{\mathrm{p}}$ from regional tomography [Eberhart-Phillips et al., 2008]. Low Qp = high attenuation. (top) Horizontal section at $30 \mathrm{~km}$ depth. SIGHT T2 transect is shown in white. Major fault traces in black. The dashed line marks the position of the cross-section illustrated in Figure 2 (bottom). (bottom) Profile through tremor region at $\mathrm{Y}=-6 \mathrm{~km}$. The white area outlines a region of high reflectivity observed in the migrated CDP'98 reflection profile (grey line in both panels) [Stern et al., 2007]. The two lines emanating from the Alpine Fault trace depict $45^{\circ}$ - and $60^{\circ}$-dipping faults.

by about $15 \mathrm{~km}$ (Figures 1 and 2). The tremor bursts collectively occur in isolated sequences limited to durations of 5-30 minutes and are equivalent in amplitude to $\mathrm{M}_{\mathrm{L}}$ 1 earthquakes. Activity repeats irregularly with a few days to several months between individual tremor sequences. Because envelope cross-correlation techniques provide poor depth control, the tremor depths are not well constrained. Some tremor appears to extend into the upper mantle; but the apparent deepening of tremor to the southwest (Figure 1) may be an artifact resulting from poor station coverage, and the $15 \mathrm{~km}$ depth uncertainty does not preclude tremor being restricted to the mid- to lower-crust. The tremor's location with respect to the SAMBA network decreases resolution and makes it difficult to employ other techniques for constraining depths and source process. Both inter-channel cross-correlation [La Rocca et al., 2009] and tremor polarization [Wech and Creager, 2007] yield results that are difficult to interpret due to poor station coverage directly above the tremor.

[10] The tremor we have identified represents the largest, most discernable examples of tremor activity in the region. It is likely that lower-level ambient tremor also occurs. However, as the durations of individual bursts get smaller, tremor becomes more difficult to detect, and distinguishing shortduration tremor from the geomorphic background noise, such as landslides and ice movement, emanating from the Southern Alps presents an additional challenge. Mainshockaftershock sequences from the Dusky Sound, Darfield and Christchurch earthquakes also reduced tremor detectability for months at a time. Overall, the observed tremor activity infrequently in random, isolated sequences and does not appear to correlate with appreciable increases or decreases in either the regional seismicity or microseismicity recorded by SAMBA (Figure S1) [Boese et al., 2012]. We do, however, note the occurrence of pronounced tremor activity just before the Dusky Sound earthquake [Beavan et al., 2010; Fry, 2009]: in the 24 hours leading up to 50 minutes before that event, we recorded two distinct sequences of tremor. This occurrence is possibly coincidental, but its timing relative to the Dusky Sound earthquake warrants mention.

\section{Discussion}

\subsection{Plate Boundary at Depth}

[11] At plate boundaries worldwide, tremor is inferred to be associated with slow shear-slip failure in the transition zone between stick-slip and stable sliding of a fault [Shelly et al., 2006, 2009; Wech and Creager, 2007]. Although our ability to resolve the depth and source process of tremor occurring in the vicinity of the Alpine Fault is limited by its position outside the SAMBA network, we interpret the tremor signals to represent slow shear failure at depth. Even given the large depth uncertainties, tremor hypocenters suggest that: 1) the majority of tremor occurs deeper than $25 \mathrm{~km}$, below the geodetically inferred locked portion of the fault (Figure 3); 2) tremor and earthquakes are anti-correlated in depth, with a gap in between (Figure 3); and 3) the tremor possibly extends to depths as great as $45 \mathrm{~km}$, potentially defining a deeper sub-vertical lineation that may distinguish itself from the $45-60^{\circ}$ dip of the Alpine Fault (Figure 3). Most of the tremor occurs at depths of $\sim 30 \mathrm{~km}$, which would place slow slip on the deep extension of the Alpine Fault (Figures 2 and 3). The depth uncertainties limit our ability to make reliable geometrical inferences; however, if the deeper tremor hypocenters are real, then tremor may not solely represent slip on the Alpine Fault, but could also incorporate slip on a near-vertical, structure defining the plate boundary at depth. In contrast, the highly reflective, southeast-dipping boundary seen in seismic reflection data (Figure 2) may represent a localized décollement surface between the lower and upper crust of the Pacific plate. Although the tremor likely represents plate [e.g., Wellman, 1979] boundary slip of some form, determining the slip geometry requires more precise depth analysis using, for example, low-frequency earthquakes comprising the tremor [Shelly et al., 2009].

\subsection{Presence of Fluids}

[12] Slow slip is often spatially correlated with regions of elevated fluid content [Audet et al., 2009; Kodaira et al., 2004; Song et al., 2009] and has been interpreted to be a 


\section{SIGHT T2 Velocity Model}

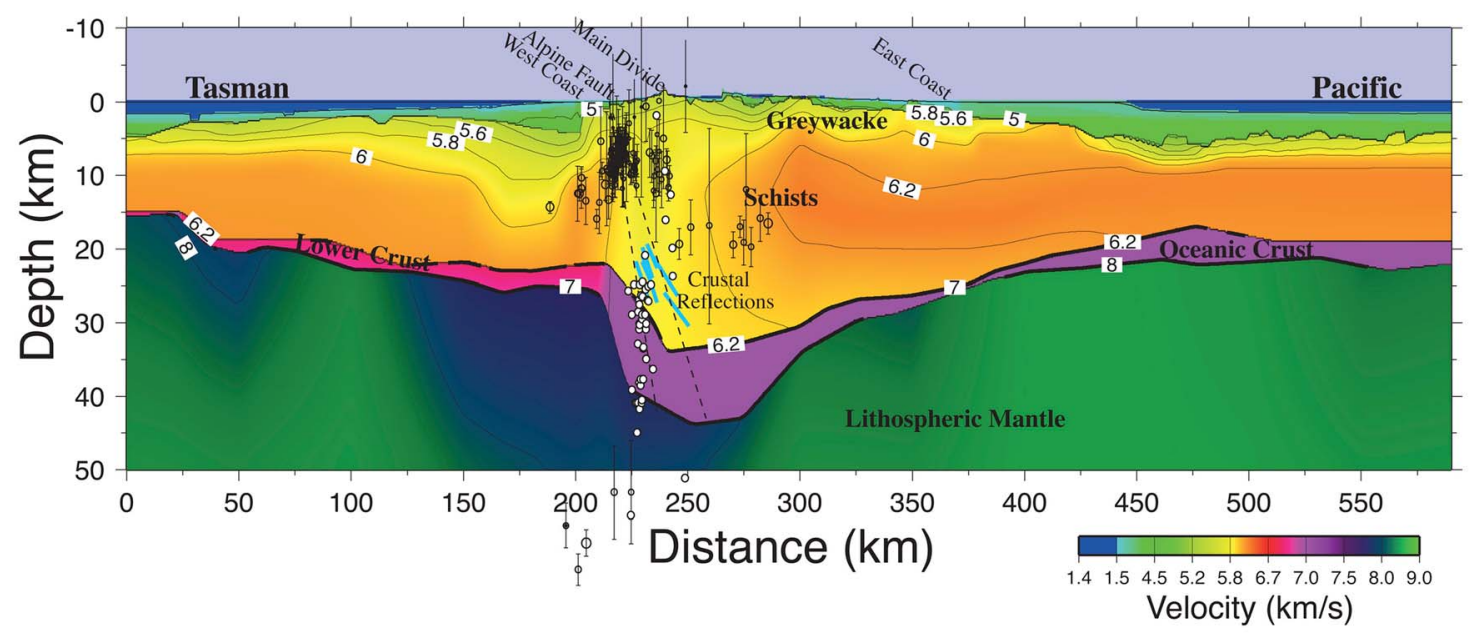

Figure 3. Local seismicity (black circles with depth uncertainty) and tremor (white circles) within $10 \mathrm{~km}$ (note difference from tremor in Figure 2) of the SIGHT T2 transect are shown on top of the preferred velocity model and interpretation [Stern et al., 2007]. Region of high reflectivity from CPD'98 [Stern et al., 2007] is shown as blue lines and dashed lines represent $45^{\circ}$ - and $60^{\circ}$-dipping faults. Tremor is anti-correlated with earthquake seismicity and occurs below the low-velocity zone at the deeper extension of the Alpine Fault. The apparent westward dip in tremor hypocenters in this cross-section is an artifact stemming from a slightly skewed projection relative to the Alpine Fault trace (see Figure 2) and vertical exaggeration.

fluid-related process. The three-dimensional P-wave attenuation $\left(1 / \mathrm{Q}_{\mathrm{p}}\right)$ structure determined from analysis of local earthquakes suggests that fluids may also be present in the tremor region beneath the Alpine Fault [Eberhart-Phillips et al., 2008]. Tremor extends downwards from the base of the seismogenic zone and overlaps with a high-attenuation zone below a depth of $25 \mathrm{~km}$ (Figure 2). This $10 \mathrm{~km}$-thick, low- $\mathrm{Q}_{\mathrm{p}}$ region exhibits the highest attenuation in the whole of South Island; Eberhart-Phillips et al. [2008] attributed it to the downdip extension of the Alpine Fault, with the high attenuation interpreted as an indicator for metamorphic fluids within a high-strain zone. Tomographic models also indicate lower P-wave velocities in the area [Eberhart-Phillips, 2002], but these are not as well resolved as the attenuation structure. However, the 2D velocity structure obtained by inverting active source data from the South Island GeopHysical Transect line 2 (SIGHT T2) [Scherwath, 2003] reveals a low-velocity zone (Figure 3 ) located above a zone of high-reflectivity inferred from a migrated seismic reflection profile, CDP'98 (Figure 2) [Stern et al., 2001, 2007]. These bright seismic reflections have been interpreted to represent interconnected fluids at lithostatic pressures produced by metamorphic dewatering of the crustal root [Stern et al., 2007] and coincide with both the tremor hypocenters and the region of high attenuation (Figure 2). We cannot determine the spatial relationship between tremor and velocity or attenuation structure further south, but given the northward increase in network density, we are confident that no significant tremor of comparable duration or equivalent magnitude occurred north of the region of high attenuation during this study period.

[13] A low-frequency signal emanating from a zone of high attenuation raises questions about path effects and the true nature of the tremor signal at its source. High attenuation can affect the frequency content of seismic signals, including tremor [Gomberg et al., 2012], making any distinction between tremor and overlapping low-frequency or normal earthquakes difficult. However, the tremor is anti-correlated with local seismicity (Figure 3), and even if it did represent an attenuated earthquake signal, the durations suggest overlapping events that might be best explained as repeated failure in response to loading from aseismic slip on the surrounding fault plane.

\subsection{Fluid-Weakened Fault}

[14] It is unclear what role fluids play in generating tremor or enabling slow slip. Nor is it entirely certain that the association of the tremor with a zone of high attenuation means that fluids play a significant role here. This observation is nevertheless consistent with the hypothesis that slip is enabled by low effective stress resulting from high fluid pressure [Audet et al., 2009; Kodaira et al., 2004], and it could explain the absence of tremor to the north. On the San Andreas Fault, tremor is correlated with small $(<1 \mathrm{kPa})$, tidal-induced stresses, providing evidence of near-lithostatic pore pressures [Thomas et al., 2009]. There, tremor occurs at similar depths [Becken et al., 2011; Nadeau and Guilhem, 2009; Shelly, 2010; Shelly and Johnson, 2011] and temperatures [Fagereng and Diener, 2011; Toy et al., 2010] to those estimated here and is similarly limited in duration [Nadeau and Dolenc, 2005] compared with tremor observed in the Cascadia or Nankai subduction zones where durations span a continuum from hours to months [Obara et al., 2010; Wech and Creager, 2011]. In the absence of direct measurements of fluid pressure deep beneath the Southern Alps, the existence of high-pressure fluids is inferred from low P-wave speeds, attenuation structure and high seismic reflectivity. However, the coincidence of tremor and inferred fluids and the similarities between Alpine Fault tremor and San Andreas Fault tremor suggest that an analogous interpretation might be applicable to the Alpine Fault. We 
therefore propose that tremor is illuminating slip occurring on the deeper, fluid-weakened extent of the plate boundary.

[15] There are, however, alternative explanations for the tremor we observe. Though slightly deeper, the detected tremor may represent slip on the inferred array of deep $(>20 \mathrm{~km})$ backshears within the hanging wall of the Alpine Fault [Wightman and Little, 2007]. Furthermore, slip could be localized to a region of high strain resulting from an alongstrike change in fault geometry. While coincident with geophysical indicators of fluids at depth, tremor epicenters also correlate spatially with an inferred change in the dip of the Alpine Fault. Structural data suggest that the fault in this region undergoes a northeastward steepening in dip by 15 $20^{\circ}$ [Little et al., 2005]. A resulting zone of localized high strain from transitional fault geometry may account for the occurrence of tremor beneath the Copland Valley section of the fault and its apparent absence to the northeast. An extension of the SAMBA array to the south is needed to test this.

\section{Implications}

[16] The Alpine Fault tremor observation expands our evidence of deep slip on transform faults beyond the San Andreas Fault and may improve understanding of the underlying physics by providing additional constraints on the conditions required for tremor and slip generation. For the Alpine Fault, the finding facilitates the use of tremor as a tool for investigating ambient conditions within the fault zone. It enables future studies to explore stress conditions and fault properties through studies of tidal [Thomas et al., 2009] and earthquake [Peng et al., 2009] triggering. More importantly, it means the fault is currently active at depth. While slow slip itself is innocuous, any such slip will redistribute stress in the vicinity and may increase the load on neighboring fault patches. This static stress transfer from slow slip has been inferred in Cascadia [Wech and Creager, 2011] as well as along the San Andreas Fault [Shelly and Johnson, 2011] and could result in seismogenic triggering, either on the Alpine Fault or an adjacent fault. Finally, the observation raises the question about the depth extent of a future Alpine Fault rupture. The tremor observations obtained to date, while sparse, enable us to infer that semi-brittle behavior extends to depths greater than either the seismogenic 10-15 km cut-off of microseismicity [Boese et al., 2012] or the geodetically inferred locked zone $(\sim 18 \mathrm{~km}$ [Wallace et al., 2007]). Refined tremor depths may elucidate the interseismic relationship between tremor, microearthquakes, and large-scale locking, providing insight into rheological controls on coseismic rupture distribution.

\section{Conclusions}

[17] We observe deep seismic tremor occurring along the Alpine Fault transform boundary between the Australian and Pacific plates. Tremor is spatially correlated with the inferred downdip extension of the Alpine Fault, high P-wave attenuation (low $\mathrm{Q}_{\mathrm{p}}$ ), and high seismic reflectivity in the crust. We attribute this tremor to fluid-enabled slow slip occurring below the seismogenic zone mainly in the lower crust, but possibly the very top of the upper mantle. This discovery marks both the first documentation of tremor associated with the Alpine Fault and the first indication of contemporary deep-slip on the plate boundary in southwestern New Zealand. Understanding deep slow slip is critical for our ability to fully characterize the conditions, dynamics and hazards of a locked fault late in its earthquake cycle.

[18] Acknowledgments. We thank the Editor, Associate Editor, Laura Wallace and an anonymous reviewer for their helpful comments on this manuscript. This research was supported by the New Zealand Marsden Fund and the New Zealand International Doctoral Research Scholarship.

[19] The Editor thanks Laura Wallace and an anonymous reviewer for assisting with the evaluation of this paper.

\section{References}

Audet, P., M. G. Bostock, N. I. Christensen, and S. M. Peacock (2009), Seismic evidence for overpressured subducted oceanic crust and megathrust fault sealing, Nature, 457, 76-78, doi:10.1038/nature07650.

Bartlow, N. M., S. Miyazaki, A. M. Bradley, and P. Segall (2011), Spacetime correlation of slip and tremor during the 2009 Cascadia slow slip event, Geophys. Res. Lett., 38, L18309, doi:10.1029/2011GL048714.

Beavan, J., et al. (1999), Crustal deformation during 1994-1998 due to oblique continental collision in the central Southern Alps, New Zealand, and implications for seismic potential of the Alpine fault, J. Geophys. Res., 104, 25,233-25,255, doi:10.1029/1999JB900198.

Beavan, J., S. Samsonov, P. Denys, R. Sutherland, N. Palmer, and M. Denham (2010), Oblique slip on the Puysegur subduction interface in the 2009 July MW 7.8 Dusky Sound earthquake from GPS and InSAR observations: Implications for the tectonics of southwestern New Zealand, Geophys. J. Int., 183, 1265-1286, doi:10.1111/j.1365-246X.2010.04798.x.

Becken, M., O. Ritter, P. A. Bedrosian, and U. Weckmann (2011), Correlation between deep fluids, tremor and creep along the central San Andreas Fault, Nature, 480, 87-90, doi:10.1038/nature10609.

Boese, C. M., J. Townend, E. Smith, and T. Stern (2012), Microseismicity and stress in the vicinity of the Alpine Fault, central Southern Alps, New Zealand, J. Geophys. Res., 117, B02302, doi:10.1029/2011JB008460.

Eberhart-Phillips, D. (2002), Three-dimensional crustal structure in the Southern Alps region of New Zealand from inversion of local earthquake and active source data, J. Geophys. Res., 107(B10), 2262, doi:10.1029/ 2001JB000567.

Eberhart-Phillips, D., M. Chadwick, and S. Bannister (2008), Threedimensional attenuation structure of central and southern South Island, New Zealand, from local earthquakes, J. Geophys. Res., 113, B05308, doi:10.1029/2007JB005359.

Evison, F. F. (1971), Seismicity of the Alpine Fault, New Zealand, Recent crustal movements, R. Soc. N. Z. Bull., 9, 161-165.

Fagereng, Å., and J. F. A. Diener (2011), San Andreas Fault tremor and retrograde metamorphism, Geophys. Res. Lett., 38, L23303, doi:10.1029/ $2011 \mathrm{GL049550.}$

Fry, B. (2009), The MW 7.6 Dusky Sound earthquake of 2009: Preliminary report, Bull. N. Z. Soc. Earthquake Eng., 43, 24- 40.

Gomberg, J., K. C. Creager, J. R. Sweet, J. E. Vidale, A. Ghosh, and A. Hotovec (2012), Earthquake spectra and near-source attenuation in the Cascadia subduction zone, J. Geophys. Res., doi:10.1029/ 2011JB009055, in press.

Johnston, M. J. S., R. D. Borcherdt, A. T. Linde, and M. T. Gladwin (2006), Continuous borehole strain and pore pressure in the near field of the 28 September 2004 M 6.0 Parkfield, California, earthquake: Implications for nucleation, fault response, earthquake prediction, and tremor, Bull. Seismol. Soc. Am., 96, S56-S72, doi:10.1785/0120050822.

Kao, H., and S.-J. Shan (2004), The Source-Scanning Algorithm: Mapping the distribution of seismic sources in time and space, Geophys. J. Int., 157, 589-594, doi:10.1111/j.1365-246X.2004.02276.x.

Kim, M. J., S. Y. Schwartz, and S. Bannister (2011), Non-volcanic tremor associated with the March 2010 Gisborne slow slip event at the Hikurangi subduction margin, New Zealand, Geophys. Res. Lett., 38, L14301, doi:10.1029/2011GL048400.

Kodaira, S., T. Iidaka, A. Kato, J.-O. Park, T. Iwasaki, and Y. Kaneda (2004), High pore fluid pressure may cause silent slip in the Nankai Trough, Science, 304, 1295-1298, doi:10.1126/science.1096535.

La Rocca, M., K. C. Creager, D. Galluzzo, S. Malone, J. E. Vidale, J. R. Sweet, and A. G. Wech (2009), Cascadia tremor located near plate interface constrained by S minus P wave times, Science, 323, 620-623, doi:10.1126/science.1167112.

Leitner, B., D. Eberhart-Phillips, H. Anderson, and J. L. Nabelek (2001), A focused look at the Alpine fault, New Zealand: Seismicity, focal mechanisms, and stress observations, J. Geophys. Res., 106, 2193-2220, doi:10.1029/2000JB900303.

Little, T. A., S. Cox, J. K. Vry, and G. Batt (2005), Variations in exhumation level and uplift rate along the obliqu-slip Alpine fault, central 
Southern Alps, New Zealand, Geol. Soc. Am. Bull., 117, 707-723, doi:10.1130/B25500.1

Nadeau, R. M., and D. Dolenc (2005), Nonvolcanic tremors deep beneath the San Andreas fault, Science, 307, 389, doi:10.1126/science.1107142.

Nadeau, R. M., and A. Guilhem (2009), Nonvolcanic tremor evolution and the San Simeon and Parkfield, California, earthquakes, Science, 325, 191-193, doi:10.1126/science.1174155.

Norris, R. J., and A. F. Cooper (2001), Late Quaternary slip rates and slip partitioning on the Alpine Fault, New Zealand, J. Struct. Geol., 23, 507-520, doi:10.1016/S0191-8141(00)00122-X.

Obara, K. (2002), Nonvolcanic deep tremor associated with subduction in southwest Japan, Science, 296, 1679-1681, doi:10.1126/science. 1070378 .

Obara, K., H. Hirose, F. Yamamizu, and K. Kasahara (2004), Episodic slow slip events accompanied by non-volcanic tremors in southwest Japan subduction zone, Geophys. Res. Lett., 31, L23602, doi:10.1029/ 2004GL020848.

Obara, K., S. Tanaka, T. Maeda, and T. Matsuzawa (2010), Depthdependent activity of non-volcanic tremor in southwest Japan, Geophys. Res. Lett., 37, L13306, doi:10.1029/2010GL043679.

Peng, Z. G., J. E. Vidale, A. G. Wech, R. M. Nadeau, and K. C. Creager (2009), Remote triggering of tremor along the San Andreas Fault in central California, J. Geophys. Res., 114, B00A06, doi:10.1029/2008JB006049.

Petersen, T., K. Gledhill, M. Chadwick, N. H. Gale, and J. Ristau (2011), The New Zealand National Seismograph Network, Seismol. Res. Lett., 82(1), 9-20, doi:10.1785/gssrl.82.1.9.

Peterson, C. L., S. R. McNutt, and D. H. Christensen (2011), Nonvolcanic tremor in the Aleutian Arc, Bull. Seismol. Soc. Am., 101, 3081-3087, doi: $10.1785 / 0120100241$.

Scherwath, M. (2003), Lithospheric structure across oblique continental collision in New Zealand from wide-angle P wave modeling, J. Geophys. Res., 108(B12), 2566, doi:10.1029/2002JB002286.

Shelly, D. R. (2010), Migrating tremors illuminate complex deformation beneath the seismogenic San Andreas Fault, Nature, 463, 648-652, doi:10.1038/nature08755.

Shelly, D. R., and K. M. Johnson (2011), Tremor reveals stress shadowing, deep postseismic creep, and depth-dependent slip recurrence on the lower-crustal San Andreas Fault near Parkfield, Geophys. Res. Lett., 38 , L13312, doi:10.1029/2011GL047863.

Shelly, D. R., G. C. Beroza, S. Ide, and S. Nakamula (2006), Lowfrequency earthquakes in Shikoku, Japan, and their relationship to episodic tremor and slip, Nature, 442, 188-191, doi:10.1038/nature04931.

Shelly, D. R., G. C. Beroza, and S. Ide (2007), Non-volcanic tremor and low-frequency earthquake swarms, Nature, 446, 305-307, doi:10.1038/ nature05666.

Shelly, D. R., W. L. Ellsworth, T. Ryberg, C. Haberland, G. S. Fuis, J. Murphy, R. M. Nadeau, and R. Burgmann (2009), Precise location of San Andreas Fault tremors near Cholame, California using seismometer clusters: Slip on the deep extension of the fault?, Geophys. Res. Lett., 36, L01303, doi:10.1029/2008GL036367.

Song, T. R. A., D. V. Helmberger, M. R. Brudzinski, R. W. Clayton, P. Davis, X. Perez-Campos, and S. K. Singh (2009), Subducting slab ultra-slow velocity layer coincident with silent earthquakes in southern Mexico, Science, 324, 502-506, doi:10.1126/science.1167595.
Stern, T., S. Kleffmann, D. Okaya, M. Scherwath, and S. Bannister (2001), Low seismic-wave speeds and enhanced fluid pressure beneath the Southern Alps of New Zealand, Geology, 29, 679-682, doi:10.1130/ 0091-7613(2001)029<0679:LSWSAE $>2.0 . \mathrm{CO} ; 2$.

Stern, T., D. Okaya, S. Kleffmann, M. Scherwath, S. Henrys, and F. Davey (2007), Geophysical exploration and dynamics of the Alpine Fault Zone, in A Continental Plate Boundary: Tectonics at South Island, New Zealand, Geophys. Monogr. Ser., vol. 175, edited by D. Okaya, T. Stern, and F. Davey, pp. 207-233, AGU, Washington, D. C., doi:10.1029/175GM11. Sutherland, R., K. Berryman, and R. Norris (2006), Quaternary slip rate and geomorphology of the Alpine fault: Implications for kinematics and seismic hazard in southwest New Zealand, Geol. Soc. Am. Bull., 118, 464-474, doi:10.1130/B25627.1.

Sutherland, R., et al. (2007), Do great earthquakes occur on the Alpine Fault in central South Island, New Zealand?, in A Continental Plate Boundary: Tectonics at South Island, New Zealand, Geophys. Monogr. Ser., vol. 175, edited by D. Okaya, T. Stern, and F. Davey, pp. 235-251, AGU, Washington, D. C, doi:10.1029/175GM12.

Thomas, A. M., R. M. Nadeau, and R. Burgmann (2009), Tremor-tide correlations and near-lithostatic pore pressure on the deep San Andreas fault, Nature, 462, 1048-1051, doi:10.1038/nature08654.

Toy, V. G., D. Craw, A. F. Cooper, and R. J. Norris (2010), Thermal regime in the central Alpine Fault zone, New Zealand: Constraints from microstructures, biotite chemistry and fluid inclusion data, Tectonophysics, 485, 178-192, doi:10.1016/j.tecto.2009.12.013.

Walcott, R. I. (1978), Present tectonics and late Cenozoic evolution of New Zealand, Geophys. J. R. Astron. Soc., 52, 137-164, doi:10.1111/j.1365246X.1978.tb04225.x.

Wallace, L. M., J. Beavan, R. McCaffrey, K. Berryman, and P. Denys (2007), Balancing the plate motion budget in the South Island, New Zealand using GPS, geological and seismological data, Geophys. J. Int., 168, 332-352, doi:10.1111/j.1365-246X.2006.03183.x.

Wech, A. G., and K. C. Creager (2007), Cascadia tremor polarization evidence for plate interface slip, Geophys. Res. Lett., 34, L22306, doi:10.1029/2007GL031167.

Wech, A. G., and K. C. Creager (2008), Automated detection and location of Cascadia tremor, Geophys. Res. Lett., 35, L20302, doi:10.1029/ 2008 GL035458.

Wech, A. G., and K. C. Creager (2011), A continuum of stress, strength and slip in the Cascadia subduction zone, Nat. Geosci., 4, 624-628, doi:10.1038/ngeo1215.

Wech, A. G., K. C. Creager, and T. I. Melbourne (2009), Seismic and geodetic constraints on Cascadia slow slip, J. Geophys. Res., 114, B10316, doi:10.1029/2008JB006090.

Wellman, H. W. (1979), An uplift map for the South Island of New Zealand, and a model for the uplift of the Southern Alps: R. Soc. N. Z. Bull, $18,13-20$.

Wightman, R., and T. A. Little (2007), Deformation of the Pacific Plate above the Alpine Fault ramp and its relationship to expulsion of metamorphic fluids: An array of backshears, in A Continental Plate Boundary: Tectonics at South Island, New Zealand, Geophys. Monogr. Ser., vol. 175, edited by D. Okaya, T. Stern, and F. Davey, pp. 177-205, AGU, Washington, D. C., doi:10.1029/175GM10. 